\title{
Variations in planktonic bacterial biomass and production, and phytoplankton blooms off A Coruña (NW Spain)*
}

\author{
JOAQUÍN VALENCIA ${ }^{1,4}$, JULIO ABALDE ${ }^{1}$, ANTONIO BODE ${ }^{2}$, ANGELES CID ${ }^{1}$, \\ EMILIO FERNÁNDEZ ${ }^{3}$, NICOLÁS GONZÁLEZ², JORGE LORENZO², \\ EVA TEIRA $^{3}$ and MANUEL VARELA ${ }^{2}$ \\ ${ }^{1}$ Departamento de Biología Celular y Molecular, Universidad de A Coruña, Campus da Zapateira, s/n. \\ 15080. A Coruña, Spain. \\ 2 Instituto Español de Oceanografía, Centro Oceanográfico de A Coruña, Apdo. 130, 15080 A Coruña Spain. \\ ${ }^{3}$ Departamento de Biología Animal y Ecología, Universidad de Vigo, Campus Lagoas - Marcosende, s/n. \\ 36200 Vigo, Spain.
}

${ }^{4}$ Present address: Instituto Español de Oceanografía, Centro Oceanográfico de Baleares, Muelle de Poniente s/n. Ap. 291, 07080 Palma de Mallorca, Spain. E-mail: joaquin.valencia@ba.ieo.es

\begin{abstract}
SUMMARY: Bacterial abundance, biomass and heterotrophic activity, along with hydrographic and phytoplankton variables, were measured from February 1998 to September 1999 at two coastal stations off A Coruña (Galicia, NW Spain). Bacterial abundance varied from 0.1 to $1.8 \times 10^{6}$ cells ml-1 and water-column integrated bacterial production ranged from 34 to $1132 \mathrm{mg} \mathrm{C} \mathrm{m}^{-2} \mathrm{~d}^{-1}$. Two annual maxima of bacterial abundance and production were observed, in spring and summer, although relatively high abundance values remained until autumn. In autumn and winter production values were low with the exception of the results obtained in November 1998, when the highest values of bacterial production of the whole study were observed at both stations. Bacterial biomass constituted a significant, but low, fraction of particulate organic carbon (4-21\%) and was always lower than phytoplankton biomass (up to $40 \%$ of phytoplankton carbon). Also, bacterial production was generally $<30 \%$ of primary production, but in some situations (as in early spring or in autumn) bacterial production exceeded primary production, suggesting a delayed response of bacterial activity after a phytoplankton bloom.
\end{abstract}

Key words: bacterial production, bacterial abundance, phytoplankton biomass, primary production, phytoplankton blooms, NW Spain.

RESUMEN: VARIACIONES EN LA BIOMASA Y PRODUCCIÓN DE LAS BACTERIAS PLANCTÓNICAS, Y EN LAS PROLIFERACIONES DE FitOPLANCTON EN LA COSTA DE A CORUÑa (NO EsPaÑa). - Se midió la abundancia, biomasa y actividad heterotrófica bacteriana, junto con variables hidrográficas y fitoplanctónicas, entre febrero de 1998 y septiembre de 1999 en dos estaciones costeras de A Coruña (Galicia, NO España). La abundancia bacteriana varió entre 0.1 y $1.8 \times 10^{6}$ células ml ${ }^{-1}$ y la producción bacteriana integrada en la columna de agua tomó valores entre 34 y $1132 \mathrm{mg} \mathrm{C} \mathrm{m}^{-2} \mathrm{~d}^{-1}$. Se observaron dos máximos de abundancia y producción bacteriana en primavera y verano, aunque se mantuvieron valores relativamente altos de abundancia durante el otoño. En otoño e invierno los valores de producción fueron bajos con la excepción de los resultados obtenidos en noviembre de 1998, donde se observaron los mayores valores de producción de todo el estudio en ambas estaciones. La biomasa bacteriana constituyó una fracción significativa, aunque baja, del carbono orgánico particulado (4-21\%) y fue siempre menor que la biomasa del fitoplancton (hasta un $40 \%$ del carbono fitoplanctónico). Del mismo modo, la producción bacteriana fue generalmente $<30 \%$ de la producción primaria, aunque en ciertas situaciones (como a principios de primavera o en otoño) la producción bacteriana excedió a la producción primaria, lo que sugiere un retraso en la respuesta de la actividad bacteriana a la proliferación del fitoplancton.

Palabras clave: producción bacteriana, abundancia bacteriana, biomasa de fitoplancton, producción primaria, proliferaciones de fitoplancton, NO España.

*Received May 15, 2002. Accepted December 3, 2002. 


\section{INTRODUCTION}

Planktonic bacteria are one of the main components of aquatic ecosystems, often constituting a significant fraction of total biomass and participating to a great extent in the flux of energy and elements like carbon. According to Cole et al. (1988), bacterial net production is equivalent on average to $30 \%$ of the water column primary production. The main sources of dissolved organic carbon for bacteria are the phytoplankton exudation and the release of dissolved substrates as a result of sloppy feeding of zooplankton (Azam et al., 1983; Furhman, 1992). Therefore, most marine bacteria depend directly or indirectly on phytoplankton. In fact, it has been observed that the bacterial production is correlated with phytoplankton biomass and production (Cole et al., 1988; White et al., 1991). However, in coastal zones some of the organic matter processed by bacteria is from allochtonous origin (Opsahl and Benner, 1997). The availability of extra food sources often results in complex seasonal variation of coastal bacterioplankton, and some studies report the lack of covariation between bacteria and phytoplankton (Hoch and Kirchman, 1993). Nevertheless, other authors have found time-lags in the response of bacterioplankton to phytoplankton blooms (Ducklow, 1993; Li et al., 1993).

The coast of A Coruña (Galicia, NW Spain) is a region of high primary production influenced by the seasonal upwelling of deep nutrient-rich waters (Varela, 1992; Bode and Varela, 1994; Casas, 1995). The upwelling occurs in the form of discrete events between March and October driven by northerly winds that cause the fertilisation of coastal and shelf waters with deep water nutrients (Fraga, 1981; Blanton et al., 1984). The dynamics of this ecosystem are based on the typical seasonal cycle of temperate seas defined by the alternance between periods of intense mixing of the water column, as in winter, and periods of water-column stratification, as in summer, although in this case the seasonal cycle is significantly modified by the upwelling (Varela, 1992; Casas, 1995). There are few data on seasonal variations of bacterioplankton off A Coruña (Varela et al., 1996; Barquero, 1999), although estimations based on data for other locations of Galicia suggest that most of phytoplankton biomass produced by the upwelling was consumed by bacteria (Bode and Varela, 1994).

The aim of this paper is to study the variability patterns in bacterial biomass and production in relation to phytoplankton productivity and proximity to the coast in a coastal area under the influence of upwelling. For this purpose, a procedure for measuring bacterial biomass and production based on some of the most widely used techniques (Porter and Feig, 1980; Kirchman, 1993) was adapted to the study area.

\section{MATERIALS AND METHODS}

\section{Sampling}

Two stations located near A Coruña (Galicia, NW Spain) were studied from February 1998 to September 1999 at approximately monthly intervals.
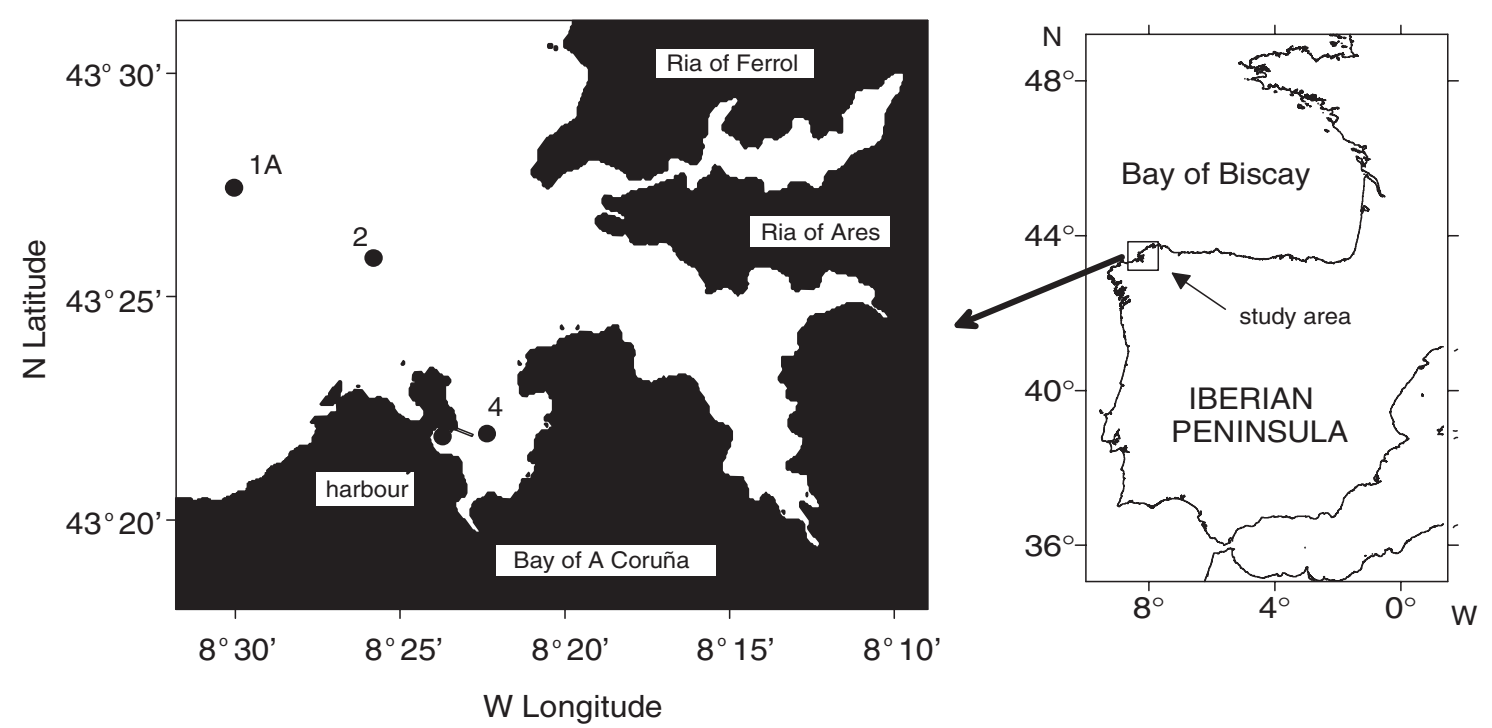

FIG. 1. - Map of the study area with location of sampling stations. 
Station $2(79 \mathrm{~m})$ was situated over the shelf and station $4(20 \mathrm{~m})$ was located at the entrance of the Bay of A Coruña (Fig. 1). At both stations temperature, salinity, in situ fluorescence, irradiance, particulate organic carbon and chlorophyll $a$ concentrations, primary production and bacterial abundance and production were measured. Vertical profiles of temperature, salinity, fluorescence and photosynthetically available radiation (PAR) were obtained with a CTD SBE-25 equipped with a LiCOR spherical sensor. Water samples were collected using 51 Niskin bottles. Sampling depths were selected following the irradiance profile at 100,50,25, 10 and $1 \%$ of surface irradiance (PAR). At station 2, two additional samples were collected above and below $1 \%$ of surface irradiance. Furthermore, additional samples were collected at station $1 \mathrm{~A}(100 \mathrm{~m})$ and in the A Coruña harbour (Fig. 1) for some experiments complementary to the bacterial production technique.

\section{Biomass and production of phytoplankton}

Particulate organic carbon (POC) was analysed following the UNESCO procedure (1994), by the filtration of 500 or $1000 \mathrm{ml}$ of seawater using Whatman GF/F glass-fibre filters. The filters were dried at $60^{\circ} \mathrm{C}$ for $24 \mathrm{~h}$ and then analyzed using a $\mathrm{CNH}$ elemental analyser (Perkin Elmer). Chlorophyll $a$ concentration was determined with a fluorimetric method (Yentsch and Menzel, 1963; Parsons et al., 1984; UNESCO, 1994) after filtration of up to 250 $\mathrm{ml}$ of water on Millipore Type $\mathrm{F}$ glass-fibre filters. Pigments were extracted with $90 \%$ acetone overnight $\left(-10^{\circ} \mathrm{C}\right)$. Chlorophyll $a$ concentrations (Chl- $a$ ) were corrected for phaeopigments after acidification with $10 \% \mathrm{HCl}$. Biomass of phytoplankton was estimated from the chlorophyll $a$ concentration using the conversion factor $50 \mathrm{~g} \mathrm{C}$ ( $\mathrm{g}$ Chla) $)^{-1}$. Primary production rates (PP) were determined as described in Bode and Varela (1998). Two transparent bottles and one dark bottle from five depths within the euphotic zone ( $>1 \%$ irradiance PAR) were inoculated with $4 \mu \mathrm{Ci}(148 \mathrm{KBq}) \mathrm{NaH}^{14} \mathrm{CO}_{3}$ and incubated in simulated in situ conditions for at least 2 hours. Light levels were simulated using neutral density screens and the incubator was refrigerated by running water. Incubations were terminated by filtration onto Millipore Type F filters. The filters were then treated with $10 \% \mathrm{HCl}$, scintillation cocktail (Ultima X-Gold, Packard) was added, and finally radioactivity was counted using a liquid scintillation counter (LKB Wallac).

\section{Bacterial abundance, biomass, and production}

Heterotrophic bacterial abundance was determined in samples preserved with glutaraldehyde (2\% final concentration) using the method of Porter and Feig (1980). Ten millilitres of each sample was filtered onto $0.2 \mu \mathrm{m}$ black, polycarbonate, Poretics membrane filters and stained with DAPI (4'-6diamino-2-phenylindole, final concentration: $2.5 \mu \mathrm{g}$ $\mathrm{ml}^{-1}$ ) for $5 \mathrm{~min}$. The filters were mounted with lowfluorescence oil on microscope slides and stored frozen. Heterotrophic bacteria were counted using ultraviolet light in an epifluorescence microscope (Olympus BH-2). Bacterial cellular carbon was estimated from biovolumes using the empirical equation of Norland et al. (1987):

$$
C=0.09 B V^{0.9}
$$

where $C$ is the carbon content ( $\mathrm{pg} \mathrm{C}$ cell $^{-1}$ ) and $B V$ is the bacterial biovolume $\left(\mu \mathrm{m}^{3}\right.$ cell $\left.^{-1}\right)$. Bacterial biovolumes were computed from measurements of bacterial dimensions using a graduated bar coupled to the microscope eyepiece. Cocci were considered as spheres and rods as cylinders.

Production of heterotrophic bacteria (BP) was estimated by ${ }^{3} \mathrm{H}$-leucine incorporation, using the method described by Kirchman (1993), substituting the final filtration of bacteria by centrifugation (Smith and Azam, 1992). Four aliquots of water samples from each depth were inoculated with ${ }^{3} \mathrm{H}$ leucine to a final concentration of $150 \mathrm{nM}$ and incubated for 30 or $45 \mathrm{~min}$ in $1.5 \mathrm{ml}$ Eppendorf vials. In addition, two $1 \mathrm{ml}$ controls killed with trichloroacetic acid (TCA, 5\% w/v final concentration) were incubated for each depth. Incubations were terminated by the addition of 5\% TCA to the incubation vials by repeated washing with 5\% TCA and successive centrifugation (12000 rpm, $10 \mathrm{~min}$ ). Scintillation cocktail (Ultima X-Gold, Packard) was added to the vials and radioactivity was measured in a liquid scintillation counter. The mean $( \pm S D)$ coefficient of variation of the radioactivity measurements between the 4 replicates for each sample was $16 \% \pm 10 \%(\mathrm{n}=235)$. The incubation was made at laboratory temperature but the measured rates were later corrected to in situ temperature. The recalculation was made using an empirically derived coefficient $\left(Q_{10}\right)$ relating leucine incorporation to temperature increases of $10^{\circ} \mathrm{C}$ (e.g. Valiela, 1995):

$$
Q_{10}=\left(r_{1} / r_{2}\right)^{\left(10 /\left(t_{1}-t_{2}\right)\right)}
$$


where $r_{1}$ and $r_{2}$ are the rates determined at temperatures $t_{1}$ and $t_{2}$. The values of $Q_{10}$ were calculated in two experiments incubating samples from the harbour station in a temperature range between -1.5 and $29.5^{\circ} \mathrm{C}$.

Linearity of leucine incorporation during the incubations was tested in time course experiments. Also, several experiments were run to ensure complete saturation of the incorporation by testing leucine concentrations between 2.5 and $320 \mathrm{nM}$ for the incubation of samples from the station $1 \mathrm{~A}$ and the harbour station. Incorporation of leucine versus concentration was adjusted to the Michaelis-Menten kinetic equation:

$$
D P M=D P M_{\text {max }}[\text { Leu }] /\left(K_{s}+[\text { Leu }]\right)
$$

where $D P M$ are the disintegrations per minute measured, $D P M_{\max }$ is the maximum DPM rate (equivalent to the maximum theorical rate of leucine incorporation), $K_{s}$ is the semisaturation constant (nM Leu) and $[\mathrm{Leu}]$ is the final concentration of leucine in the incubation vials (nM Leu). The constants $D P M_{\max }$ and $K_{s}$ were obtained by adjusting by linear regression to the equation:

$$
[L e u] / D P M=a+b[\text { Leu }]
$$

where $K_{s}=a / b$ and $D P M_{\max }=1 / b$.

The conversion factors between leucine incorporation and cell growth or carbon production were determined experimentally by the procedures indicated in Kirchman and Ducklow (1993). For each experiment $200 \mathrm{ml}$ of surface seawater from station $1 \mathrm{~A}$ or the harbour station was added to $800 \mathrm{ml}$ of autoclaved seawater and incubated at room temperature for $50 \mathrm{~h}$. Every 3 or $4 \mathrm{~h}$, aliquots of this culture were removed for the determination of bacterial abundance and leucine incorporation rates by the described procedures.

Daily rates were used for comparing bacterial production with primary production values integrated in the water column. For this purpose, it was assumed that bacterial production was constant during the day, as some studies suggest that daily variations in bacterial production in coastal zones are not very pronounced (e.g. Gasol et al., 1998). Daily primary production was computed from hourly rates multiplied by the number of sunlight hours, which were determined according to the model of Straskraba and Gnauck (1985).

Bacterial growth rates $(\mu)$ were computed as:

$$
\mu=\ln (1+B P / B B)
$$

and the corresponding duplication time (DT) as:

$$
D T=\ln 2 / \mu
$$

Comparison of bacterial and phytoplankton biomass and production was made by integrating all biomass and production values in the whole water-column (surface to $79 \mathrm{~m}$ depth in the station 2 and surface to $20 \mathrm{~m}$ in station 4 ).

\section{RESULTS}

\section{Methodological settings for bacterial production}

No significant differences were found between the mean biovolumes of bacteria from stations, 2, 4 and the harbour station (Table 1, ANOVA p >0.05). The mean biovolume obtained was $0.13( \pm 0.14$, SD) $\mu \mathrm{m}^{3}$ cell- $^{-1}(\mathrm{n}=408)$, with a resulting carbon content of 14.25 ( \pm 14.84 , SD) fg C cell ${ }^{-1}$. However, given the relatively large variances observed for each station, we applied the respective mean carbon content of bacteria from stations 2 or 4 in all subsequent computations of biomass or production.

In all saturation experiments complete saturation was not reached until leucine incorporation generally exceeded $100 \mathrm{nM}$ (Fig. 2). However, high leucine concentrations $(>200 \mathrm{nM})$ produce an inhibition of incorporation. Because a saturating concentration of $100 \mathrm{nM}$ is high compared with other studies (Kirchman, 1993; Wiebinga et al., 1997; Gasol et al., 1998) we explored the possibility of the existence of a first saturation at concentrations $<50 \mathrm{nM}$, while at higher concentrations inactive bacteria are stimulated (Fig. 2, Table 2). This stimulation would result in the existence of a new logarithmic growth phase, but the presence of this phase in our results is not apparent, since most experiments were best described by a single Michaelis-Menten curve (Fig. 2). In the absence

TABLE 1. - Bacterial biovolume in three different zones (mean and standard deviation, SD) and transformation to the carbon content using the ecuation of Norland et al. (1987).

\begin{tabular}{lccccc}
\hline & \multicolumn{3}{c}{ Biovolume $\left(\mu \mathrm{m}^{3}\right)$} & \multicolumn{3}{c}{ Biomass $\left(\mathrm{fg} \mathrm{C}\right.$ cell $\left.^{-1}\right)$} \\
Station & Mean & $\mathrm{SD}$ & $\mathrm{n}$ & Mean & $\mathrm{SD}$ \\
\hline harbour & 0.15 & 0.15 & 121 & 15.93 & 16.42 \\
2 & 0.13 & 0.17 & 145 & 14.25 & 17.78 \\
4 & 0.11 & 0.07 & 142 & 12.75 & 8.54 \\
Mean: & 0.13 & 0.14 & 408 & 14.25 & 14.84 \\
\hline
\end{tabular}



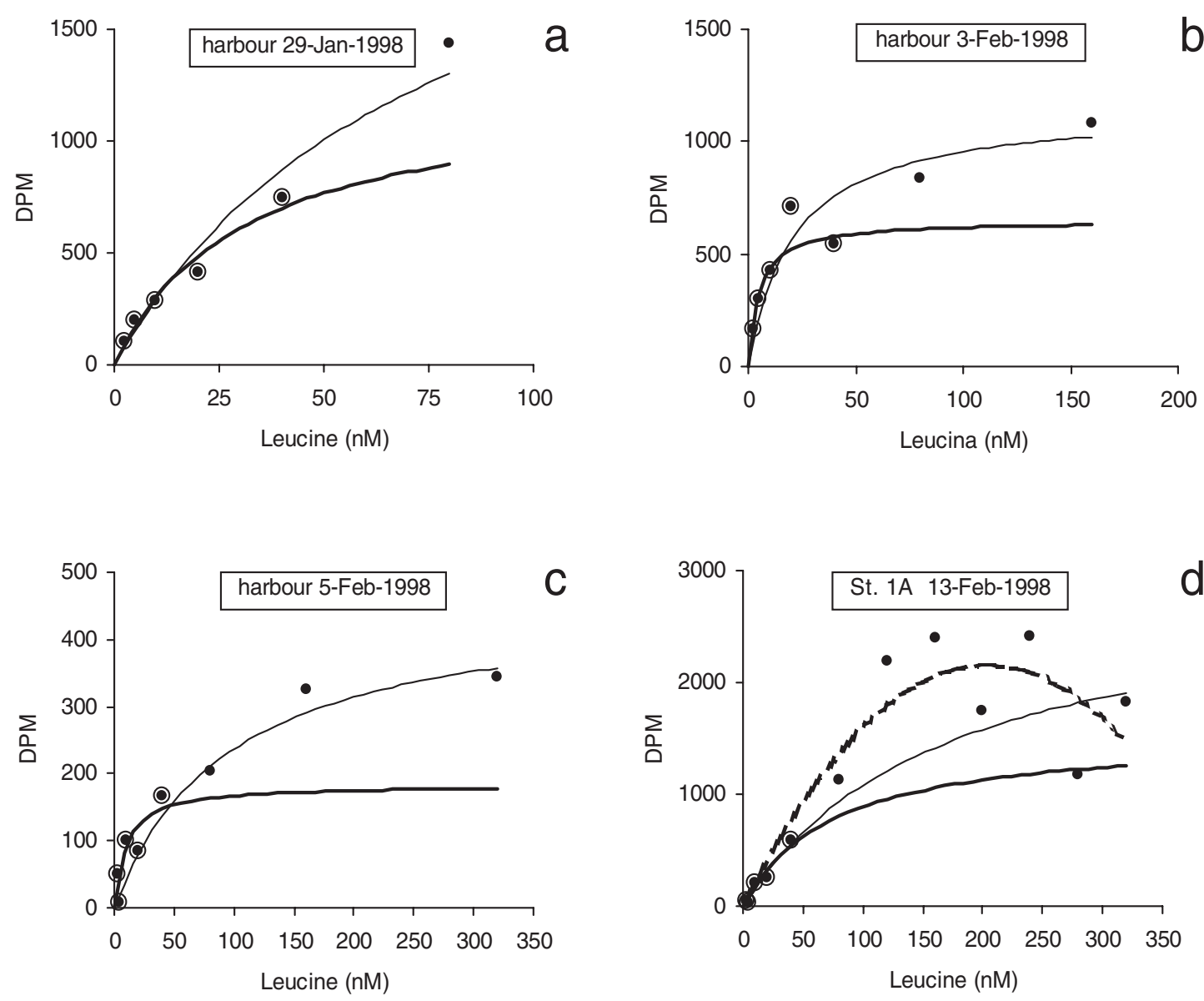

FIG. 2. - Incorporation of labeled leucine (as disintegrations per minute, DPM) at different initial concentrations of substrate. Continuous lines indicate curves fitted to Michaelis-Menten functions using either all data points (fine line) or only those points corresponding to leucine concentrations up to $50 \mathrm{nM}$ (thick lines). The parameters of the Michaelis-Menten curves are in Table 2. Incubations were done with samples of the harbour ( $\mathrm{a}, \mathrm{b}$ and $\mathrm{c}$ ) or station 1A (d). The dotted curve in d was fitted to all data points by using a polynomial function only for descriptive purposes.

of information about the actual concentration of leucine in the study area, and according to the experiments carried out, we used a concentration of 150 $\mathrm{nM}$ in all subsequent incubations. Nevertheless, from the values of the Michaelis-Menten saturation equation constants (Table 2) we estimated that the addi-

TABLE 2. - Values of the estimated Michaelis-Menten parameters for the four experiments done with increasing final concentrations of leucine. $K$ : semisaturation constant (nM Leu), $D P M_{\text {a }}$ : theorical maximum DPM rate, $D P M_{150}$ : disintegrations per minute estimated from the Michaelis-Menten equation for a final concentration of $150 \mathrm{nM}, D P M_{50}$ : disintegrations per minute estimated from the Michaelis-Menten ecuation for a final concentration of $50 \mathrm{nM}$, factor: relation between $D P M_{150}$ and $D P M_{50}, S D$ : standard deviation.

\begin{tabular}{|c|c|c|c|c|c|c|}
\hline Station & Date & $K_{s}$ & $D P M_{\max }$ & $D P M_{150}$ & $D P M_{50}$ & factor \\
\hline harbour & 29-Jan-1998 & 77.2 & 2555.1 & 1686.9 & 1004.4 & 1.7 \\
\hline harbour & 3-Feb-1998 & 21.1 & 1156.7 & 1014.3 & 813.9 & 1.2 \\
\hline harbour & 5-Feb-1998 & 96.5 & 465.5 & 283.3 & 158.9 & 1.8 \\
\hline \multirow[t]{3}{*}{$1 \mathrm{~A}$} & 13-Feb-1998 & 171.3 & 2929.8 & 1367.7 & 661.9 & 2.1 \\
\hline & & & & & Mean: & 1.7 \\
\hline & & & & & SD: & 0.3 \\
\hline
\end{tabular}

tion of leucine up to $150 \mathrm{nM}$ would have multiplied the incorporation rates expected at $50 \mathrm{nM}$ by 1.2 to 2.1 times.

In two incubation experiments made at different temperatures a positive correlation between temperature and bacterial production was found (overall $\mathrm{r}=$

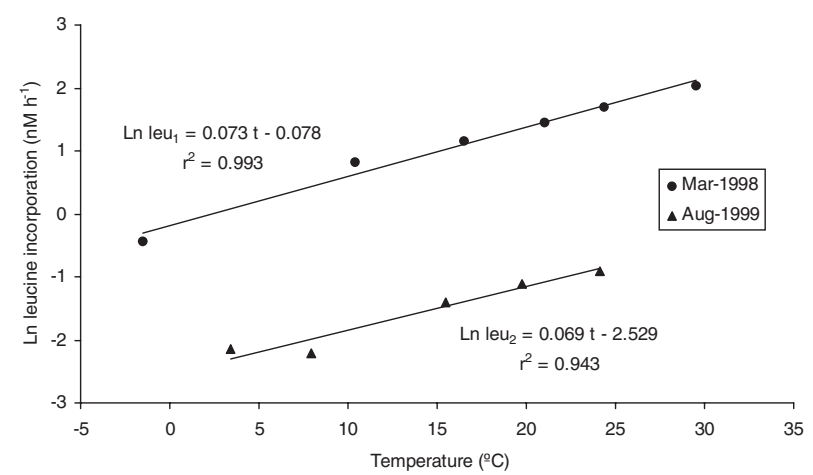

FIG. 3. - Incorporation of leucine at different incubation temperatures. Experiments were done with samples of the harbour on March 1998 and August 1999. 


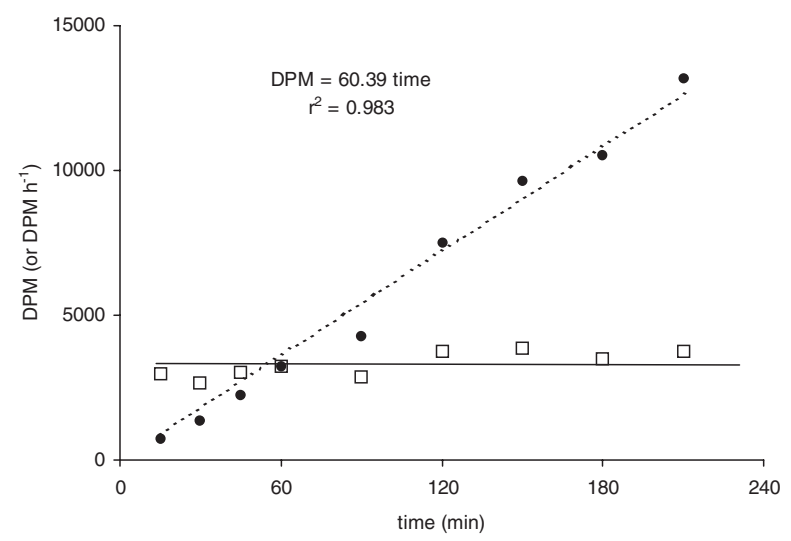

FIG. 4. - Time course leucine incorporation (as disintegrations per minute, DPM). The accumulation of labeled leucine was shown by the dotted line and the linear function, while the resulting leucine incorporation rate $\left(\mathrm{DPM} \mathrm{h} \mathrm{h}^{-1}\right)$ was aproximately constant during the experiment (continuous line).

0.984, p < 0.01, Fig. 3), but no significant differences were observed between the slopes of the regression line relating bacterial production and temperature computed separately for each experiment (t-Student Test, $\mathrm{p}>0.1$ ). From these experiments we obtained a mean $Q_{10}$ value of 2.02 which was used to recalculate bacterial production rates at
TABLE 3. - Empirical conversion factors between leucine and cell growth or carbon uptake. Cell to carbon uptake conversion was made using the estimated cell biomass for each station (Table 1) SD: standard deviation.

\begin{tabular}{lcc}
\hline Date & Station & $\begin{array}{c}\text { Conversion Factor } \\
{\left[\mathrm{x} \mathrm{10} \text { 10 }^{17} \text { cell }(\mathrm{mol} \mathrm{leu})^{-1}\right]}\end{array}$ \\
\hline 11-Feb-1998 & harbour & 4.44 \\
6-Mar-1998 & 1 A & 3.02 \\
24-Mar-1998 & harbour & 2.37 \\
23-Feb-1999 & harbour & 6.74 \\
24-Mar-1999 & 1A & 2.10 \\
4-May-1999 & harbour & 2.83 \\
& Mean: & 3.58 \\
& SD: & 1.60 \\
\hline
\end{tabular}

in situ temperature.

Time-course experiments revealed that the relation between leucine incorporation and incubation time was linear for at least 210 minutes (Fig. 4). Therefore, there was no difference between the results obtained with the two incubation times used (30 or 45 minutes).

Leucine incorporation was converted to carbon production using an empirical conversion factor derived from six experiments with a mean $( \pm$ SD)
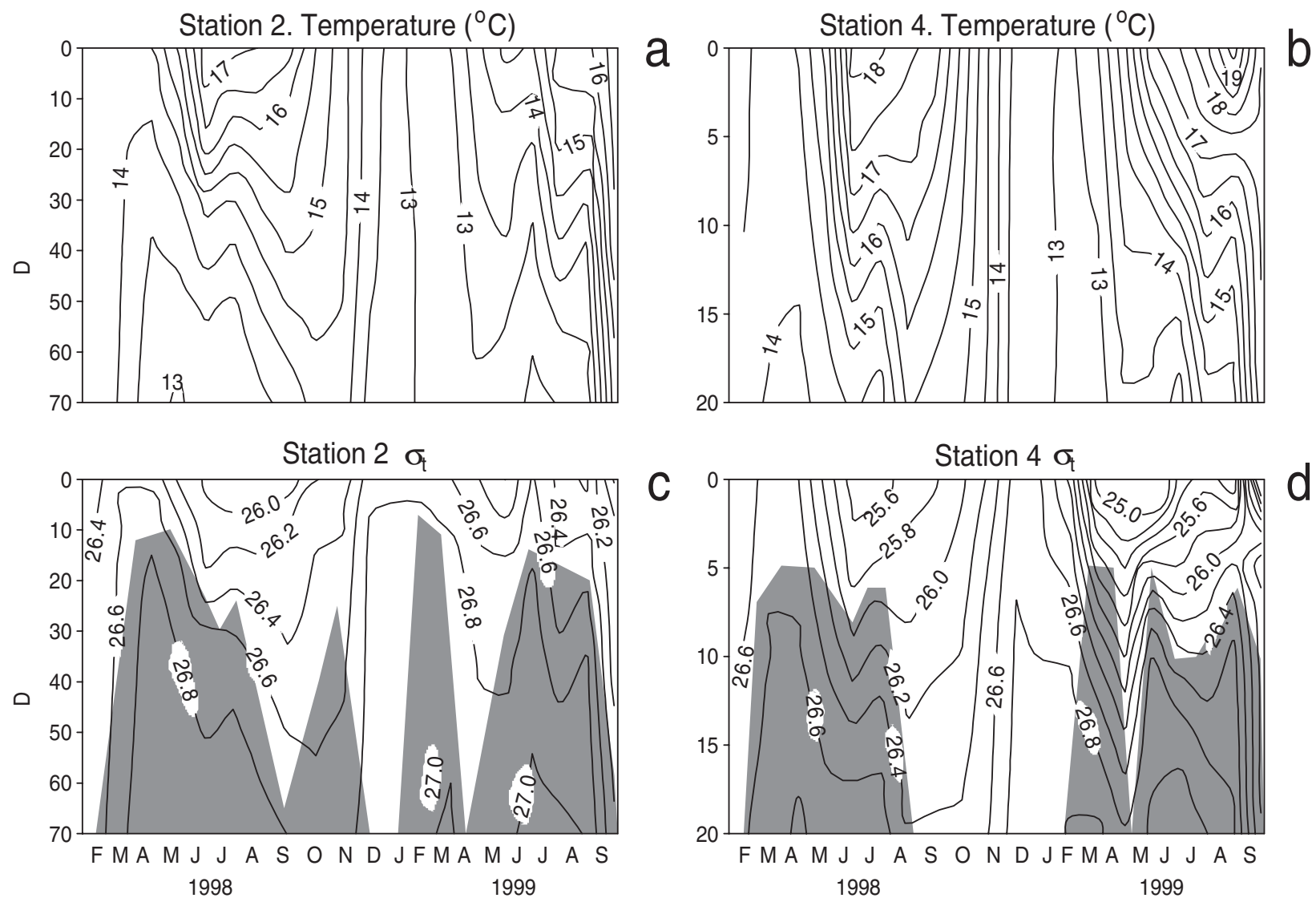

FIG. 5. - Distribution of temperature and $\sigma_{t}$ during the study at stations $2(\mathrm{a}, \mathrm{c})$ and 4 (b, d). The shaded area indicates the layer below the upper mixing layer. 

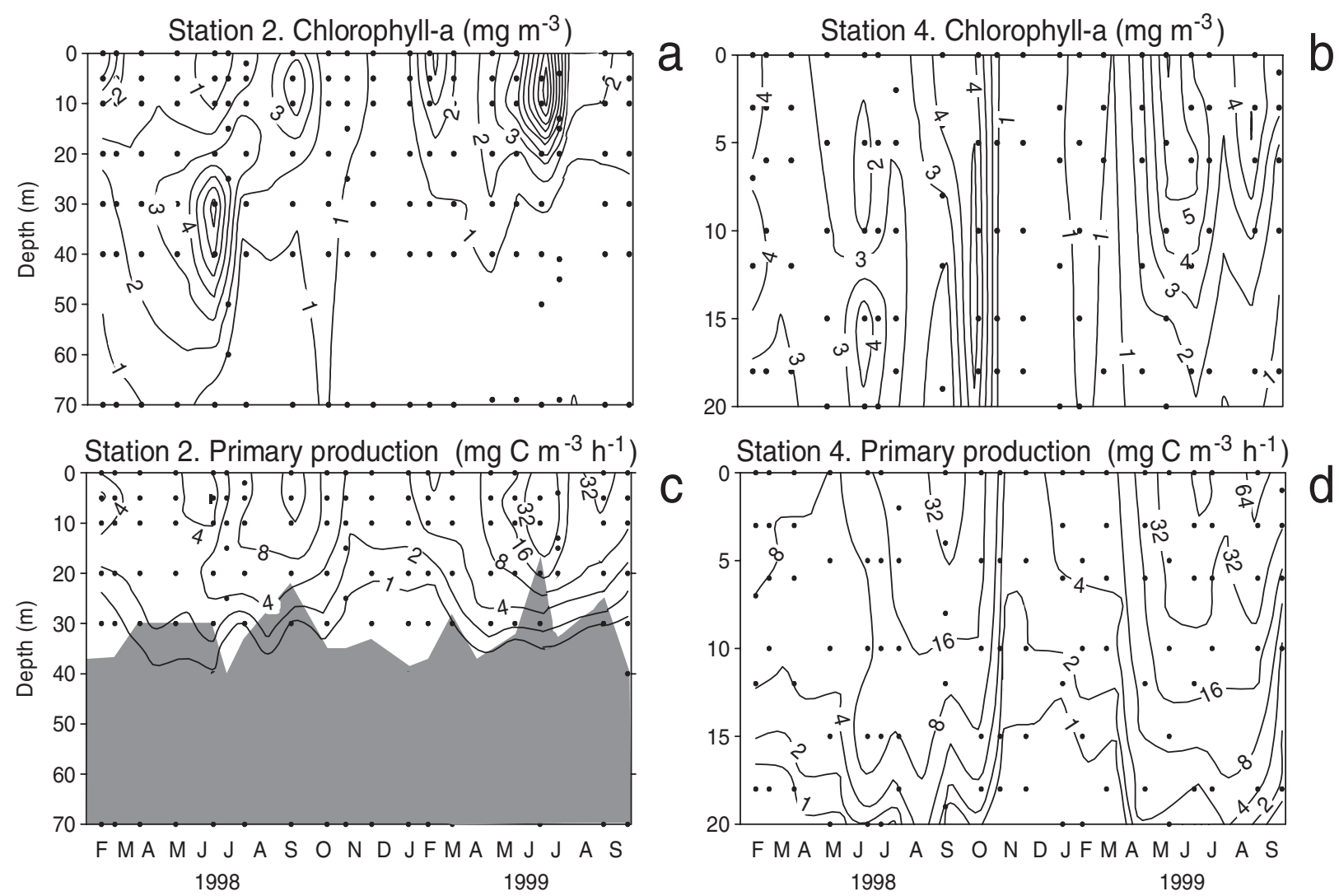

FIG. 6. - Distribution of chlorophyll-a concentrations and primary production during the study at stations 2 (a, c) and 4 (b, d). The shaded area indicates the layer below the euphotic zone (i.e. $<1 \%$ of surface PAR irradiance)

value of $3.58( \pm 1.6) \times 10^{17}$ cell (mol leucine $)^{-1}$ (Table 3). Taking into account the mean biomass values computed (Table 1), the resulting conversion factors for stations 2 and 4 were 5.11 and $4.57 \mathrm{~kg} \mathrm{C}$ (mol leucine $)^{-1}$ respectively.

\section{Environmental variability}

Upwelling conditions were detected in May and July 1998, and in June and September 1999 (Figs. 5a and 5b). The upwelling events were traced at both stations, although more clearly at station 2 . The downwelling situations were observed at the end of September in both years, and they were characterised by a deepening of the mixing layer (Figs. 5c and $5 \mathrm{~d}$ ) caused by the accumulation of surface water towards the coast.

There were interannual differences in the timing of the stratification and mixing periods. In 1998, the stratification period at station 2 began in April and continued until November (Fig. 5a). In 1999, the stratification began in February and remained until September, and even when no thermal stratification was observed in January and April of this year there was a thin layer of haline stratification near the surface. Nevertheless, in both years the maximum depth of the mixing layer during the stratification period (58 and $65 \mathrm{~m}$ respectively) was observed in September during downwelling conditions.

Similar changes were observed at the coastal station. In 1998 the pycnocline of this station was formed in March and could be recognised until September 1998 (Figs. 5b and 5c). The maximum depth of the mixing layer during the stratification period was observed in June. In 1999 the stratification period began in February and remained until September. As at station 2, there was no thermal stratification in April 1999, but there was haline stratification. (Fig. 5d). The upper mixing layer reached a maximum of $10 \mathrm{~m}$ depth in June, July and at the end of September.

\section{Phytoplankton biomass and production}

The main phytoplankton blooms occurred between February and September (Fig. 6). The highest values of biomass and production coincided with or occurred immediately after the upwelling pulses. Biomass maxima in the water column were 
TABLE 4. - Surface-to-bottom integrated values of phytoplankton biomass (PB), primary production (PP), bacterial biomass (BB), bacterial production (BP) and concentration of particulate organic carbon (POC). Biomass and POC values are given in $\mathrm{mg} \mathrm{C}^{-2}$, while production values are given in $\mathrm{mg} \mathrm{C} \mathrm{m}^{-2} \mathrm{~d}^{-1}$. SD: standard deviation, $\mathrm{n}$ : number of cases.

\begin{tabular}{|c|c|c|c|c|c|c|c|c|c|c|}
\hline Date & $\mathrm{PB}$ & $\begin{array}{r}\text { Station } 2 \\
\mathrm{PP}\end{array}$ & $\mathrm{BB}$ & $\mathrm{BP}$ & POC & $\mathrm{PB}$ & $\begin{array}{r}\text { ation } 4 \\
\text { PP }\end{array}$ & BB & BP & POC \\
\hline Feb-1998 & 5895 & 895 & 998 & 382 & 4666 & 3741 & 1061 & 295 & - & 2719 \\
\hline Mar-1998 & 3282 & 86 & 1299 & 721 & 6449 & 2059 & 252 & 333 & 571 & 3046 \\
\hline Apr-1998 & 8427 & 1292 & 987 & 887 & - & 3945 & 1606 & 242 & 723 & 3262 \\
\hline May-1998 & 7016 & 875 & 773 & 632 & 6402 & 2893 & 1046 & 253 & 247 & 3795 \\
\hline Jun-1998 & 12234 & 1269 & 507 & 296 & 6900 & 3196 & 2387 & 171 & 306 & 3132 \\
\hline Jul-1998 & 5037 & 1937 & 609 & 443 & 4646 & 2861 & 2835 & 206 & 149 & 2900 \\
\hline Aug-1998 & 5182 & 2240 & 1058 & 502 & 8214 & 3043 & 2830 & 239 & 347 & 5070 \\
\hline Sep-1998 & 6270 & 3453 & 677 & 79 & 8441 & 2427 & 3682 & 175 & 43 & 4725 \\
\hline Oct-1998 & 5040 & 1092 & 764 & 167 & 8107 & 4699 & 1983 & 180 & 55 & 2927 \\
\hline Nov-1998 & 2185 & 462 & 415 & 1010 & 6512 & 540 & 257 & - & 190 & 2583 \\
\hline Dec-1998 & 2237 & 440 & 421 & 56 & 7800 & 717 & 272 & 116 & 86 & 3207 \\
\hline Jan-1999 & 2089 & 464 & 497 & 54 & 4725 & 702 & 365 & 142 & 88 & 3456 \\
\hline Feb-1999 & 5513 & 1100 & 594 & 54 & 5271 & 1599 & 556 & 121 & 63 & 1848 \\
\hline Mar-1999 & 1532 & 378 & 544 & 102 & - & 522 & 332 & 111 & 69 & 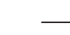 \\
\hline Apr-1999 & 6377 & 3572 & 392 & 262 & 6519 & 1293 & 1766 & 123 & 110 & 1657 \\
\hline May-1999 & 4703 & 4147 & 433 & 454 & 4963 & 2943 & 6423 & 127 & 1132 & 2857 \\
\hline Jun-1999 & 13496 & 12543 & 634 & 212 & 7220 & 4201 & 6952 & 272 & 96 & 4844 \\
\hline Jul-1999 & 2657 & 2367 & 478 & 89 & 5729 & 1905 & 2944 & 275 & 34 & 2446 \\
\hline Aug-1999 & 2925 & 3543 & 443 & 229 & 6067 & 3241 & 6420 & 186 & 209 & 2322 \\
\hline Sep-1999 & 3405 & 1699 & - & 478 & 6607 & 1490 & 1771 & - & 253 & 2523 \\
\hline Mean & 5275 & 2193 & 659 & 355 & 6402 & 2401 & 2287 & 198 & 251 & 3122 \\
\hline SD : & 3202 & 2723 & 259 & 285 & 1239 & 1277 & 2126 & 69 & 281 & 936 \\
\hline $\mathrm{n}:$ & 20 & 20 & 19 & 20 & 18 & 20 & 20 & 18 & 19 & 19 \\
\hline
\end{tabular}
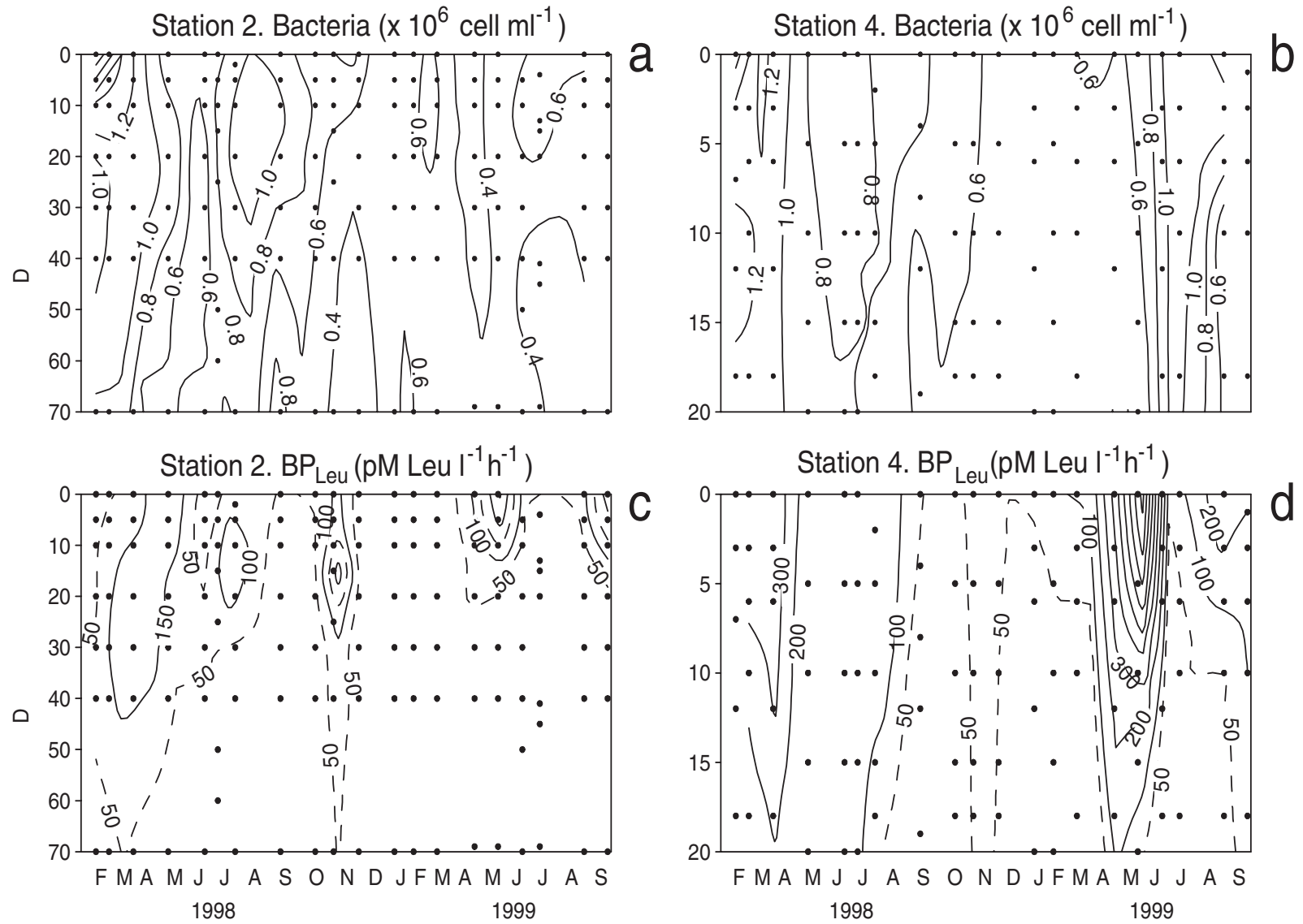

FIG. 7. - Distribution of bacterial abundance and leucine incorporation during the study at stations 2 (a, c) and 4 (b, d). 
located near the surface or in a subsurface layer (e.g. at $30 \mathrm{~m}$ depth at station 2 in June 1998), whereas the peaks of photosynthetic production were generally situated near the surface (i.e. in the upper $10 \mathrm{~m}$ ). Minimum values were obtained during winter mixing conditions (between November and January), when biomass and production values were low and without fluctuations. During downwelling situations the values of biomass and production were relatively high, but lower than those observed during upwelling conditions. Integrated phytoplankton biomass ranged from 1532 to $13496 \mathrm{mg} \mathrm{C} \mathrm{m}^{-2}$ at station 2 and from 522 to $4699 \mathrm{mg} \mathrm{C} \mathrm{m}^{-2}$ at station 4 (Table 4). Correspondingly, primary production ranged from 86 to $12543 \mathrm{mg} \mathrm{C} \mathrm{m}^{-2} \mathrm{~d}^{-1}$ at station 2, and from 252 to $6952 \mathrm{mg} \mathrm{C} \mathrm{m}^{-2} \mathrm{~d}^{-1}$ at station 4 (Table 4).

\section{Bacterial biomass and production}

Bacterial abundance varied between 0.1 and 1.8 x $10^{6}$ cells $\mathrm{ml}^{-1}$, with a very similar pattern in both stations (Fig. 7). Two annual maxima were observed, in spring and summer, and values remained relatively high until autumn. The vertical distribution in the water column showed peaks generally located above the pycnocline. In fact, the pycnocline was a discontinuity in the abundance profiles, below which the distribution of bacterial abundance was fairly homogenous. However, in some cases the peaks of bacterial biomass were located near the bottom (e.g. February and April 1999 at station 2), probably due to the resuspension of sediments in periods of high vertical mixing. Water-column integrated bacterial biomass ranged from 392 to $1299 \mathrm{mg} \mathrm{C} \mathrm{m}^{-2}$ at station 2 and from 111 to 333

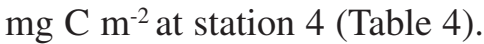

Seasonal changes in bacterial production (Figs. $7 \mathrm{c}$ and $7 \mathrm{~d}$ ) followed those of abundance and were very similar at both stations. Two annual maxima were found, one in mid- spring and the other in summer, the latter lower than the former. In autumn and winter production values were low with the exception of the results obtained in November, when the highest values of production of the whole study were observed at both stations. However, low bacterial production values were also found in some summer samples, such as those of July 1999.

Water-column integrated values varied between 54 and $1010 \mathrm{mg} \mathrm{C} \mathrm{m}^{-2} \mathrm{~d}^{-1}$ at station 2 and between 34 and $1132 \mathrm{mg} \mathrm{C} \mathrm{m}^{-2} \mathrm{~d}^{-1}$ at station 4 (Table 4), which represents a wider range of variation than those found for biomass.

\section{Relationships between bacteria and phytoplankton}

As expected, there was a significant, positive correlation between bacterial production and bacterial biomass (Table 5), although it only accounted for < $12 \%$ of the variance in production. In turn, biomass and production of bacteria were significantly correlated with most environmental and phytoplankton variables (Table 5). Negative correlation values between bacterial production and depth, salinity and $\sigma_{t}$ were the consequence of the location of maximum production values near the surface, and their occurrence mostly in spring and summer. Bacterial biomass was negatively correlated with depth, but not with salinity or $\sigma_{t}$. However, both bacterial variables were positively correlated with temperature, POC, chlorophyll and primary production.

The deeper water-column at station 2 than at station 4 can be related to some of the differences found in sestonic and bacterial variables between the two stations (Table 6). For instance, water-column integrated values of $\mathrm{PB}, \mathrm{POC}$ and $\mathrm{BB}$ at station 2 were significantly higher than those at station 4 . However, when volumetric data were considered, the values of PB and POC (but not BB) at station 4 were significantly higher than those at station 2 . Such differences were maintained in the ratios between BB and PB or POC, which reached signifi-

TABLE 5. - Values of Pearson correlation coefficients between bacterial variables and some environmental variables calculated from the volumetric values. Significance levels are indicated by asterisks: (*) $\mathrm{p}<0.05,(* *) \mathrm{p}<0.01,(* * *) \mathrm{p}<0.001$, n.s.: non significant differences $(p>0.05)$. The number of data used in each correlation is indicated between brackets. $S$ : salinity, t: temperature, $\sigma_{\mathrm{t}}$ : density, POC: particulate organic carbon, Chl-a: chlorophyll-a, PP: primary production, BB: bacterial biomass, BP: bacterial production.

\begin{tabular}{lcc}
\hline & BB & BP \\
\hline Depth & $-0.23 * * *$ & $-0.23 * * *$ \\
& $(\mathrm{n}=223)$ & $(\mathrm{n}=232)$ \\
$\mathrm{S}$ & $\mathrm{n} . \mathrm{s}$. & $-0.34 * * *$ \\
& $(\mathrm{n}=223)$ & $(\mathrm{n}=232)$ \\
$\mathrm{t}$ & $0.31 * * *$ & $0.30 * * *$ \\
& $(\mathrm{n}=223)$ & $(\mathrm{n}=232)$ \\
$\sigma_{\mathrm{t}}$ & $-0.22 * *$ & $-0.45 * * *$ \\
$\mathrm{(n}=223)$ & $(\mathrm{n}=232)$ \\
POC & $0.31 * * *$ & $0.34 * * *$ \\
& $(\mathrm{n}=203)$ & $(\mathrm{n}=213)$ \\
Chl-a & $0.27 * * *$ & $0.29 * * *$ \\
& $(\mathrm{n}=222)$ & $(\mathrm{n}=231)$ \\
$\mathrm{PP}$ & $0.15 *$ & $0.29 * * *$ \\
& $(\mathrm{n}=185)$ & $(\mathrm{n}=194)$ \\
BB & - & $0.18 * *$ \\
& & $(\mathrm{n}=215)$ \\
BP & $0.34 * * *$ & - \\
& $(\mathrm{n}=207)$ & \\
\hline
\end{tabular}


TABLE 6. - Results of Mann-Whitney tests of the differences between mean values at stations 2 and 4 using either water-colum integrated or volumetric data of phytoplankton biomass (PB), particulate carbon (POC), primary production (PP), bacterial biomass $(\mathrm{BB})$, bacterial production $(\mathrm{BP})$, bacterial growth rate $(\mu)$, and the ratios $\mathrm{BP} / \mathrm{PB}, \mathrm{BP} / \mathrm{PP}$ and $\mathrm{BB} / \mathrm{POC}$. Significance levels are indicated by asterisks: $(*) \mathrm{p}<0.05,(* *) \mathrm{p}<0.01,(* * *) \mathrm{p}<0.001$, n.s.: non significant differences $(\mathrm{p}>0.05)$, n: number of cases. The ranking of significant mean values is indicated in brackets where applicable.

\begin{tabular}{|c|c|c|c|c|}
\hline Variable & $\mathrm{n}$ & $\begin{array}{l}\text { Integrated values } \\
\text { Significance }\end{array}$ & $\mathrm{n}$ & $\begin{array}{c}\text { Volumetric values } \\
\text { Significance }\end{array}$ \\
\hline PB & 40 & $* * *(\mathrm{St} 2>\mathrm{St} 4)$ & 239 & $* * *(\mathrm{St} 2<\mathrm{St} 4)$ \\
\hline POC & 37 & $* * *(\mathrm{St} 2>\mathrm{St} 4)$ & 220 & $* * *(\mathrm{St} 2<\mathrm{St} 4)$ \\
\hline PP & 40 & n.s. & 200 & $*(\mathrm{St} 2<\mathrm{St} 4)$ \\
\hline $\mathrm{BB}$ & 37 & $* * *(\mathrm{St} 2>\mathrm{St} 4)$ & 223 & n.s. \\
\hline $\mathrm{BP}$ & 39 & n.s. & 232 & $* * *(\mathrm{St} 2<\mathrm{St} 4)$ \\
\hline BB/PB & 37 & $*(\mathrm{St} 2>\mathrm{St} 4)$ & 222 & $* * *(\mathrm{St} 2>\mathrm{St} 4)$ \\
\hline $\mathrm{BB} / \mathrm{POC}$ & 34 & $*(\mathrm{St} 2>\mathrm{St} 4)$ & 203 & $* * *(\mathrm{St} 2>\mathrm{St} 4)$ \\
\hline $\mathrm{BP} / \mathrm{PP}$ & 39 & n.s. & 200 & n.s. \\
\hline$\mu$ & 36 & $*(\mathrm{St} 2<\mathrm{St} 4)$ & 232 & $* * *(\mathrm{St} 2<\mathrm{St} 4)$ \\
\hline
\end{tabular}
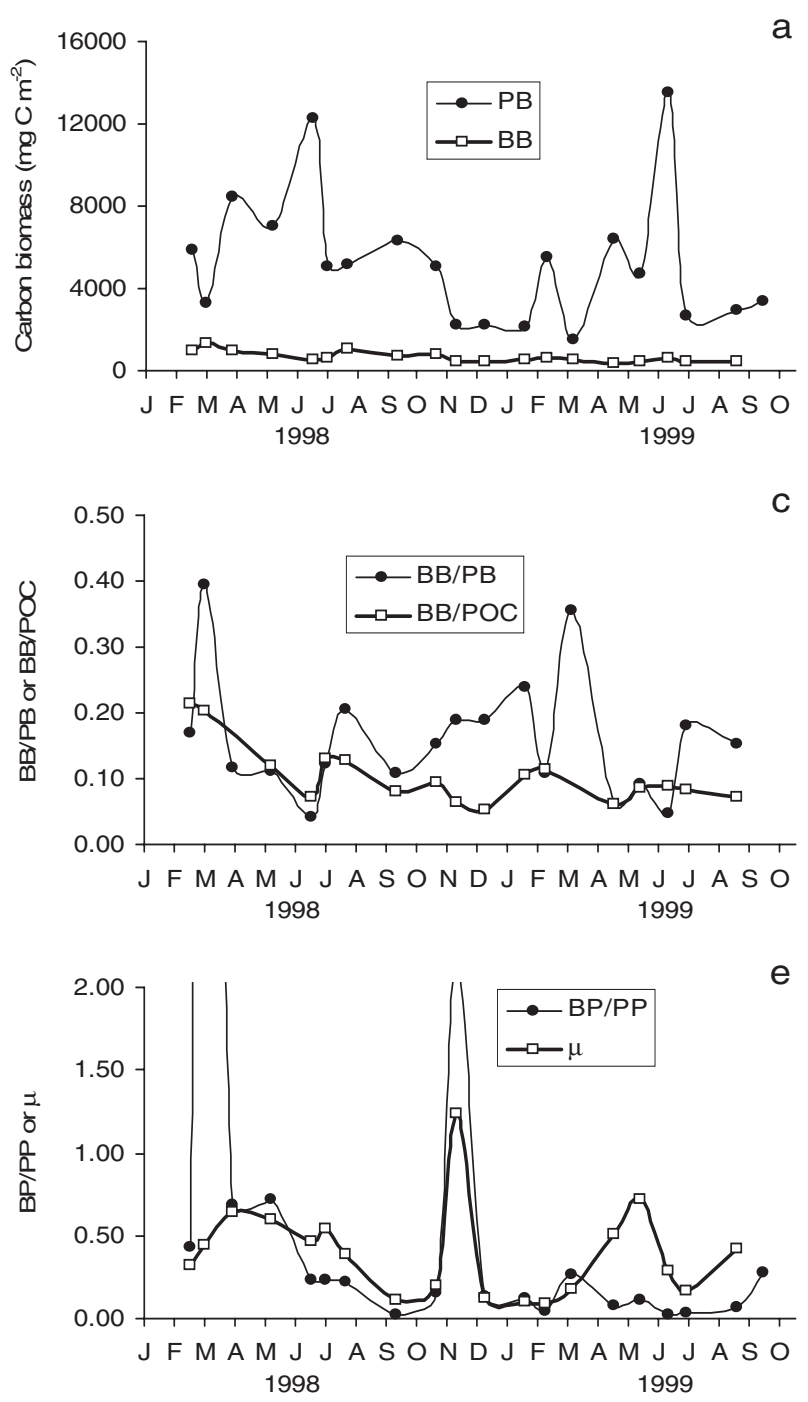

cantly higher values at station 2 than at station 4 , either using integrated or volumetric data. Such differences indicate that, despite the differences in depth between stations, average phytoplankton and seston concentrations were higher near the coast, while bacterial biomass was more constant. Furthermore, the values of both PP and BP were not significantly different between stations for water-column integrated data, but volumetric values at station 4 were significantly higher than those at station 2, indicating a relative enhancement of both phytoplankton and bacterial production rates near the coast. Also, station 4 displayed significantly higher bacterial growth rates (water-column mean $\pm \mathrm{SD}=$ $\left.0.71 \pm 0.52 \mathrm{~d}^{-1}, \mathrm{n}=17\right)$ than station $2\left(0.40 \pm 0.28 \mathrm{~d}^{-1}\right.$, $\mathrm{n}=19$ ), which are equivalent to average biomass
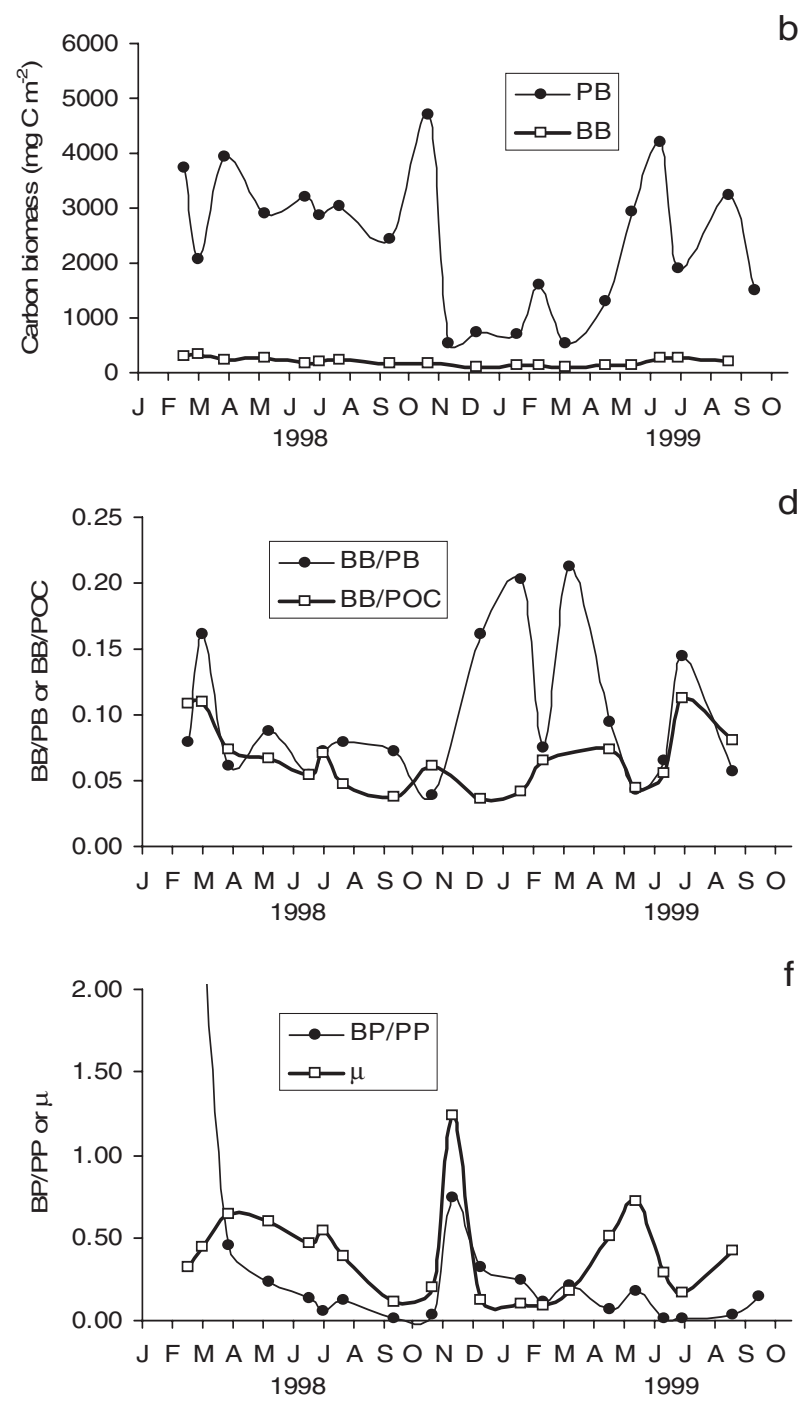

FIG. 8. - Seasonal variation of surface-to-bottom integrated $\mathrm{PB}$ abd $\mathrm{BB}$, along with ratios $\mathrm{BB} / \mathrm{PB}, \mathrm{BB} / \mathrm{POC}$ and $\mathrm{BP} / \mathrm{PP}$, and bacterial growth rates $(\mu)$ for station $2(a, c, e)$ and station $4(b, d, f)$. 
duplication times of 0.98 and 1.73 days respectively. Interestingly, the BP increase was, on average, proportional to that of PP, since there were no significant differences between stations in the BP/PP ratio either using integrated or volumetric data (Table 6).

Water-column integrated bacterial biomass was always lower than phytoplankton biomass. At station 2, BB/PB ratio ranged from 4 to $40 \%$, while at station 4 it ranged from 4 to $21 \%$ (Fig. 8). As occurred with $\mathrm{BB} / \mathrm{PB}, \mathrm{BB} / \mathrm{POC}$ ratio values displayed a wider range at station $2(5$ to $21 \%$ ) than at station 4 (4 to $11 \%)$. The variability in the ratios between bacterial and phytoplankton or seston carbon stocks and between production of bacteria and phytoplankton was related to the appearance of the main blooms of phytoplankton (Fig. 8). The occurrence of these blooms, marked by high increases in water-column integrated phytoplankton biomass, could not be traced as correspondingly high increases in $\mathrm{BB}$ at any of the studied stations. Also, relative increases in average $\mathrm{BB} / \mathrm{POC}$ or $\mathrm{BB} / \mathrm{PB}$ ratios were displaced in time between the main peaks of phytoplankton, and a similar pattern was found in bacterial growth rates and BP/PP ratios. However, there were occasional cases in which the peaks in PB were coincident with peaks in bacterial growth rates, as in April 1998 at both stations and in August 1999 at station 4 (Fig. 8). It must be noted that the values of BP/PP exceeding $100 \%$ observed in March 1998 at both stations coincided with the lowest value of primary production, while the high value in November 1998 was caused by an increase in bacterial production.

\section{DISCUSSION}

\section{Estimation of bacterial production}

The main methodological aspects that affect the estimation of bacterial production using the method of leucine incorporation are the utilisation of a saturating leucine concentration and the conversion from leucine incorporation to cells and carbon units (Kirchman, 1993). Large additions of leucine are used to avoid the utilisation of unlabeled leucine and for repressing de novo synthesis of intracellular leucine (Kirchman, 1993). There are not many publications with experimental determinations of the saturating concentrations in natural populations of marine bacteria. Therefore, while Kirchman (1993) recommends a final concentration of $10 \mathrm{nM}$,
Wiebinga et al. (1997) in bacteria from the Somalia Current and Gasol et al. (1998) in the Mediterranean found a saturating concentration of $20 \mathrm{nM}$. These values contrast with the results obtained in the saturation experiments of this study (where the leucine incorporation saturates at $>100 \mathrm{nM}$ ), which could led to an overestimation of BP because of an artificial stimulation of the bacteria. However, recent studies on the Galician shelf showed saturating leucine concentrations of $160 \mathrm{nM}$, which are equivalent to those employed in this study (Barbosa et al., 2001). Also, Van Looij and Rieman (1993) concluded that it was necessary to add up to $230 \mathrm{nM}$ of leucine to minimise isotope dilution in bacteria from an eutrophic fjord. Moreover, there are studies showing that the addition of leucine at concentrations $>100 \mathrm{nM}$ does not artificially stimulate bacterial production during short incubations (Kirchman et al., 1985; Chin-Leo and Kirchman, 1988; Simon and Azam, 1989; Van Looij and Riemann, 1993).

The second important aspect affecting the estimation of bacterial production (and also bacterial biomass) is the carbon content per cell. The mean carbon content obtained in this study (14.25 fg C cell $^{-1}$ at station 2 and $12.75 \mathrm{fg} \mathrm{C}$ cell $^{-1}$ at station 4) are equivalent to those found in other studies, such as those of in bacteria from the Galician margin (6.1-12.6, Barbosa et al., 2001), from the Bay of Biscay (11.35 fg C cell ${ }^{-1}$, Iriberri et al., 1990), from the Nordic fjords (from 7 to $19 \mathrm{fg} \mathrm{C}^{\mathrm{C}}$ cell-1, Fagerbakke et al., 1996) and even from oceanic zones (12.4 fg C cell-1 ${ }^{-1}$ Fukuda et al., 1998). Nevertheless, our results are lower than those of the majority of the studies about marine bacterioplankton $\left(20 \mathrm{fg} \mathrm{C} \mathrm{Cell}^{-1}\right.$, Lee and Fuhrman, 1987), as well as those in recent determinations in coastal and oceanic bacteria from other places (30.2 $\mathrm{fg} \mathrm{C}$ cell $^{-1}$, Fukuda et al., 1998; 17 fg C cell-1 ${ }^{-1}$ Bode et al., 2001), which suggest that bacterial biomass estimations of this study are conservative.

In contrast, the conversion factor between leucine and carbon production used in this study is higher than those employed in other studies (Table 7), including the theoretical range of $1.5-3.1 \mathrm{Kg} \mathrm{C}$ mol $^{-1}$ suggested by Simon and Azam (1989). For instance, had we applied the theoretical conversion factor, the values of bacterial production of stations 2 and 4 would have been 0.67 and 0.61 times lower respectively. However, the mean leucine-to-cell conversion factor employed in our computations was the average of 6 different experiments made at different sampling times and covering extreme situa- 
TABLE 7. - Conversion factors between leucine incorporation (mol), increase of the cells number and carbon production in different studies. The range or the mean value is indicated.

\begin{tabular}{|c|c|c|c|}
\hline $\begin{array}{l}\text { Conversion factor in cell units } \\
\left(10^{17} \text { cells } \mathrm{mol}^{-1}\right)\end{array}$ & $\begin{array}{l}\text { Conversion factor in carbon units } \\
\qquad\left(\mathrm{Kg} \mathrm{C} \mathrm{mol}^{-1}\right)\end{array}$ & Reference & Observations \\
\hline & $1.5-3.1$ & Simon and Azam (1989) & Theoretical \\
\hline $0.7^{\text {(a) }}$ & & Hoch and Kirchman (1993) & Estuary \\
\hline $0.6-1.7$ & & Li et al.(1993) & Open ocean \\
\hline $0.2-3.0$ & & Carlson et al. (1994) & Open ocean \\
\hline \multirow[t]{2}{*}{$0.2-3.3$} & & Kirchman (1992) & Open ocean \\
\hline & $0.3-2.1$ & Gasol et al. (1998) & Coast and open ocean \\
\hline \multirow[t]{3}{*}{$0.7-2.5$} & $0.4-4.3$ & Bode et al. (2001) & Open ocean \\
\hline & $0.2-0.8$ & Barbosa et al. (2001) & Shelf waters \\
\hline & $2.3^{\text {(a) }}$ & Biddanda et al. (1994) & Coast \\
\hline $2.1-6.7$ & $4.6-5.1$ & This study & Coast \\
\hline
\end{tabular}

(a) mean value.

tions within the study area. Moreover, the absolute values of bacterial carbon production obtained are not particularly high when compared with other studies in marine ecosystems (Cole et al., 1988; White et al., 1991). Therefore, a general overestimation of BP because of the use of high conversion rates in our study is not likely.

\section{Spatial variations}

The differences in bacterial growth rate between the two stations, caused mainly by the relatively higher values of $\mathrm{BP}$ at the coastal station compared to those observed on the shelf, suggest the existence of different bacterial populations living in each environment or, alternatively, the existence of an environmental difference at the coastal station enhancing bacterial growth. In support of the first hypothesis we noted that, though mean size was not significantly different between stations, bacteria from station 2 displayed a high variability in individual size, which suggests the existence of a highly diverse population. On the other hand, high BP near the coast may be the consequence of high concentrations of organic susbtrates which would be readily used by bacteria. Although measurements of dissolved organic carbon concentrations or production rates were not available for the coastal station during the study, we found significantly higher POC and PB at the coastal station than at the shelf station. Such a difference could also be paralleled by dissolved organic carbon, as found at other locations of Galicia (Doval et al., 1997). Other studies have also noted the high availability of dissolved organic carbon for bacterial growth near the coast compared to offshore environments (Ducklow and Carlson, 1992; Ducklow, 2000).

\section{Temporal variations}

The variations in oceanographic conditions and phytoplankton reported in this study agree with those described for this ecosystem (Valdés et al., 1991; Casas, 1995; Bode et al. 1996; Varela et al. 1996; Casas et al., 1997, 1999; Bode and Varela, 1998; Barquero, 1999), although the maximum value of primary production found during the upwelling of June 1999 (12543 $\left.\mathrm{mg} \mathrm{C} \mathrm{m}^{-2} \mathrm{~h}^{-1}\right)$ is the highest ever recorded in this ecosystem.

Bacterial abundance values in this study are within the range found before at station 2 between January 1995 and December 1997 (0.6-30.6 x 10 cell $\mathrm{ml}^{-1}$, Barquero, 1999), as well as within the range of the published values for other coastal areas in northern Spain (Hanson et al., 1986; Unanue et al., 1992; Tenore et al., 1995; Barquero et al., 1998; Morán et al., 1999; Barbosa et al., 2001; Varela et $a l$., in press), with the exception of abundance values of highly eutrophic systems such as the Ría de

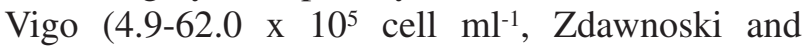
Figueiras, 1997). The relatively low variation in bacterial abundance when compared with other variables (e.g. bacterial production, phytoplankton production and biomass) was also noted in other studies (Carlson et al., 1996; Wiebinga et al., 1997)

In relation to bacterial production, there are no previous measurements on the coast of A Coruña, although some studies made some estimates of bacterial production from biomass and conversion factors from the literature (e.g. Bode and Varela, 1994; Barquero, 1999). In this study, the minimum value of bacterial production $\left(4.8 \times 10^{-2} \mathrm{mg} \mathrm{C} \mathrm{m}^{-3} \mathrm{~d}^{-1}\right)$ coincides with the minimum found by Tenore et al. (1995) in samples from the Galician shelf, while the maximum production (145.2 $\left.\mathrm{mg} \mathrm{C} \mathrm{m}^{-3} \mathrm{~d}^{-1}\right)$ is higher 
than most values reported (1.0-3.8 $\mathrm{mg} \mathrm{C} \mathrm{m}^{-3} \mathrm{~d}^{-1}$, Hanson et al., 1986; $13.9-48.6 \mathrm{mg} \mathrm{C} \mathrm{m}^{-3} \mathrm{~d}^{-1}$, average of cold and warm season respectively, Unanue et al., 1992; 0.1-28.7 mg C m $\mathrm{m} \mathrm{d}^{-1}$, Tenore et al., 1995; 0.9$48.4 \mathrm{mg} \mathrm{C} \mathrm{m}^{-3} \mathrm{~d}^{-1}$, Barquero et al., 1998; 0.13-3.52 mg C m ${ }^{-3} \mathrm{~d}^{-1}$, Barbosa et al., 2001), but is similar to values recently measured in the nearby Ría de Ferrol (0.3-162.6 $\mathrm{mg} \mathrm{C} \mathrm{m}^{-3} \mathrm{~d}^{-1}$, Varela et al., in press). Cole et al. (1988) found a mean value ( \pm SD) for the bacterial production of marine and freshwaters planktonic ecosystems of $26 \pm 33 \mathrm{mg} \mathrm{C} \mathrm{m}^{-3} \mathrm{~d}^{-1}$, while White et al. (1991) cited a mean value for marine ecosystems of $18 \mathrm{mg} \mathrm{C} \mathrm{m}^{-3} \mathrm{~d}^{-1}$. Considering that the mean value ( $\pm \mathrm{SD}$ ) of this study is $12 \pm 17 \mathrm{mg} \mathrm{C} \mathrm{m}^{-3}$ $\mathrm{d}^{-1}$, we can conclude that the measured values of bacterial production were low in comparison with most aquatic ecosystems. However, these comparisons must be interpreted in a rather general way given the different bacterial biovolumes, radiolabeled substrates and concentrations used to estimate incorporation of carbon by bacteria in different studies.

When considering factors controlling bacterial production, some studies in upwelling areas found a negative relationship between upwelling pulses and bacterial production (Sorokin and Kogelschatz, 1979; Sorokin, 1981; Hanson et al., 1986; Bak and Nieuwland, 1993; Tenore et al., 1995; Barquero et al., 1998), concluding that the latter decays during the initial stages of the upwelling process but increases as the upwelling relaxes. However, in this study there was no clear relation between upwelling pulses and bacterial production, probably because the sampling frequency employed was not very suitable for the study of this relationship. Also, temperature was generally an important factor influencing bacterial production in most ecosystems (White et al., 1991; Ducklow and Shiah, 1993) but in our results it only explained less than $9 \%$ of the variance in bacterial production.

\section{Bacteria and phytoplankton}

Bacterial biomass was always lower than phytoplankton biomass, as expected in a eutrophic area (Gasol et al., 1997). Ducklow and Carlson (1992) affirm that the BB/PB ratio of coastal zones is generally $<0.2$, which is consistent with our results for the coastal station, but not for station 2 , where values of this ratio were frequently $>0.2$. The seasonal variation of the ratio $\mathrm{BB} / \mathrm{PB}$ reflects mostly seasonal changes in phytoplanktonic biomass, so this ratio is high when the phytoplankton biomass is low and conversely, as bacterial biomass was relatively less variable. Our results also agree with published regressions between bacterial abundance and chlorophyll-a, which had slope values $<1$ (Ducklow and Carlson, 1992; Gasol et al., 1997; Gasol and Duarte, 2000, and references therein), indicating that the relative contribution of bacteria to total planktonic biomass decreases when autotrophic biomass increases. The BB/POC ratio values found in this study were higher than those found by Varela $e t$ al. (1988) in a late spring bloom in the Galician coast and lower than those of a spring bloom in the North Atlantic (Ducklow et al., 1993). Nevertheless, the value of $\mathrm{BB} / \mathrm{POC}$ estimated in the Galician margin (Barbosa et al., 2001) and at neritic stations in the Bay of Biscay during summer (Barquero et al., 1998) are close to the range found in this study.

According to Cole et al. (1988) the mean value for the integrated $\mathrm{BP} / \mathrm{PP}$ is 0.3 for different aquatic ecosystems, although recently Ducklow (2000) suggested that the average value would rather be between 0.1 and 0.2. Barbosa et al. (2001) reported variations of BP/PP ratio near 0.7 during upwelling episodes on the south Galician shelf. During our study most values of the BP/PP ratio were $<0.3$, but in some situations (as in early spring or in autumn) this ratio can be $>1$. Such extremely high values can be interpreted as the delayed response of bacterial activity after a phytoplankton bloom. In this regard, there are reports of BP/PP ratio values of between 0.5 and 1 after phytoplankton blooms (Lucas et al., 1986; McManus and Peterson, 1988; Ducklow, 1993), suggesting that these situations were nonsteady, transient periods of biomass decomposition (Wiebinga et al., 1997). In contrast, during periods of low primary production bacterial activity would be closely coupled to the release of phytoplanktonic dissolved organic matter. Although in our results bacterial production was significantly correlated with phytoplankton biomass and production, the influence of these variables on bacterial production within the studied ecosystem was notably lower than in cross-system analysis (Cole et al., 1988).

In conclusion, planktonic bacteria constitute a significant, but low, fraction of POC in the pelagic ecosystem of A Coruña, characterised in general by high biomass of phytoplankton. Despite a relatively constant biomass, bacterial production can reach values far exceeding concurrently measured primary production rates. Such excesses in bacterial production are likely to occur after phytoplankton blooms. The higher bacterial growth rates at the coastal site 
than at the shelf station were probably the consequence of differences in the bacterial communities living in each environment, but also of the high concentration of organic substrates near the coast.

\section{ACKNOWLEDGEMENTS}

We are grateful to the crew of the R/V Lura for their assistance during sampling. We would also like to express our thanks for the collaboration of Begoña Castro in processing and counting bacterial samples, and to Pilar Iglesias, Marisa Fermoso and Carlos Cariño for their assistance in the processing of plankton and chemical samples. We also thank H.W. Ducklow and an anonymous referee for making valuable suggestions to an earlier version of the manuscript. This research was supported by the XUGA-10302B98 project of the Xunta de Galicia (Spain), and by funds of the Instituto Español de Oceanografía (project IEO-1007).

\section{REFERENCES}

Azam, F., T. Fenchel, J.G. Field, J.S. Gray, L. A. Meyer-Reil and F. Thingstad. - 1983. The ecological role of water-column microbes in the sea. Mar. Ecol. Prog. Ser., 10: 257-263.

Bak, R.P.M. and G. Nieuwland. - 1993. Patterns in pelagic and benthic nanoflagellate densities in the coastal upwelling system along Banc d'Arguin, Mauritania. Hydrobiol., 258: 119-131.

Barbosa, A.B., H.M. Galvao, P.A Mendes, X.A. Álvarez-Salgado, F.G. Figueiras and I. Joint. - 2001. Short-term variability of heterotrophic bacterioplankton during upwelling off the NW Iberian margin. Prog. Oceanogr., 51: 339-359.

Barquero, S. - 1999. Regeneración de nutrientes como control de la producción primaria planctónica por los heterótrofos. $\mathrm{PhD}$ Thesis, Universidad de Oviedo. Spain.

Barquero, S., J.A. Botas and A. Bode. - 1998. Abundance and production of pelagic bacteria in the southern Bay of Biscay during summer. Sci. Mar., 62: 83-90.

Biddanda, B., S. Opsahl and R. Benner. - 1994. Plankton respiration and carbon flux through bacterioplankton on the Louisiana shelf. Limnol. Oceanogr., 39: 1259-1275.

Blanton, J.O., L.P. Atkinson, F. Fernández De Castillejo and A. Lavín. - 1984. Coastal upwelling off the Rías Bajas, Galicia, Northwest of Spain. I: Hydrographic studies. Rapp. Proc.-verb. Réu. Cons. Int. Expl. mer, 183: 79-90.

Bode, A. and M. Varela. - 1994. Planktonic carbon and nitrogen budgets for the N-NW Spanish shelf: The role of pelagic nutrient regeneration during upwelling events. Sci. Mar.. 58: 221-231.

Bode, A. and M. Varela. - 1998. Primary production and phytoplankton in three Galician Rias Altas (NW Spain): seasonal and spatial variability. Sci. Mar., $62: 319-330$.

Bode, A., S. Barquero, M. Varela, J.G. Braun and D. Armas. 2001. Pelagic bacteria and phytoplankton in oceanic waters near the Canary Islands in summer. Mar. Ecol. Prog. Ser., 209: 1-17.

Bode, A., B, Casas, E. Fernández, E. Marañón, P. Serret and M. Varela. - 1996. Phytoplankton biomass and production in shelf waters off NW Spain: spatial and seasonal variability in relation to upwelling. Hydrobiol., 341: 225-234.

Carlson, G.A., H.W. Ducklow and A.F. Michaels - 1994. Annual flux of dissolved organic carbon from the euphotic zone in the northwestern Sargasso Sea. Nature, 371: 405-408.

Carlson, G.A., H.W. Ducklow and T.D. Sleeter. - 1996. Stocks and dynamics of bacterioplankton in the northwestern Sargasso Sea. Deep-Sea Res. II., 43: 491-515.

Casas, B. - 1995. Composición, Biomasa y Producción del Fitoplancton en la Costa de La Coruña. PhD Thesis. Universidade de Santiago de Compostela. Spain.

Casas, B., M. Varela and A. Bode. - 1999. Seasonal succession of phytoplankton species on the coast of A Coruña (Galicia, northwest Spain). Bol. Inst. Esp. Oceanogr. 15(1-4): 413-429.

Casas, B., M. Varela, M. Canle, N. González and A. Bode. - 1997. Seasonal variations of nutrients, seston and phytoplankton, and upwelling intensity off La Coruña (NW Spain). Estuar. Coast. Shelf Sci., 44: 767-778.

Chin-Leo, G. and D.L. Kirchman. - 1988. Estimating bacterial production in marine waters from simultaneous incorporation of thymidine and leucine. Appl. Environ. Microbiol., 54: 19341939

Cole, J.J., Findlay, S. and Pace, M.L. - 1988. Bacterial production in fresh and saltwater ecosystems: a cross-system overview. Mar. Ecol. Prog. Ser., 43: 1-10.

Doval, M.D., X.A. Álvarez-Salgado and F.F. Pérez - 1997. Dissolved organic matter in a temperate embayment affected by coastal upwelling. Mar. Ecol. Prog. Ser., 157: 21-37.

Ducklow, H.W. - 1993. Bacterioplankton distributions and production in the northwestern Indian Ocean and Gulf of Oman, September 1986. Deep Sea Res. II, 40(3): 753-771.

Ducklow, H.W. - 2000. Bacterial production and biomass in the oceans. In: D.L. Kirchman (Ed.), Microbial Ecology of the Oceans, pp. 85-120. Wiley-Liss, Inc, New York.

Ducklow, H.W. and G.A. Carlson. - 1992. Oceanic bacterial production. In: K.C. Marshall (Ed.), Advances in microbial ecology. 12: 113-181. Plenum press, New York.

Ducklow H.W. and F.K. Shiah. - 1993. Bacterial production in estuaries. In: T.E. Ford (Ed.), Aquatic microbiology. An ecological approach, pp. 261-287. Blackwell Scientific Publications, Oxford.

Ducklow, H.W., D.L. Kirchman, H.L. Quinby, C.A. Carlson and H.G. Dam. - 1993. Stocks and dynamics of bacterioplankton carbon during the spring bloom in the eastern North Atlantic Ocean. Deep-Sea Res. II, 40: 245-263.

Fagerbakke, K.M., M. Heldal and S. Norland. - 1996. Content of carbon, nitrogen, oxygen, sulfur and phosphorus in native aquatic and cultured bacteria. Aquat. Microb. Ecol., 10: 15-27.

Fraga, F. - 1981. Upwelling off the Galician coast, NW Spain. In: F.A. Richards (Ed.), Upwelling ecosystems, pp. 176-182. American Geophysical Union, Washington D.C.

Fukuda, R., H. Ogawa, T. Nagata and I. Koike. - 1998. Direct determination of carbon and nitrogen contents of natural bacterial assemblages in marine environments. Appl. Environ. Microbiol., 64: 3352-3358.

Fuhrman, J. - 1992. Bacterioplankton roles in cycling of organic matter: the microbial food web. In: P.G. Falkowski and A.D Woodhead (Eds.), Primary Productivity and Biogeochemical Cycles in the Sea, pp. 361-383. Plenum Press, New York.

Gasol, J.M., P.A. Del Giorgio and C.M. Duarte. - 1997. Biomass distribution in marine planktonic communities. Limnol. Oceanogr., 42:1353-1363.

Gasol, J.M., M.D. Doval, J. Pinhassi, J.I. Calderón-Paz, N. GuixaBoixareu, D. Vaqué and C. Pedrós-Alió. - 1998. Diel variations in bacterial heterotrophic activity and growth in the northwestern Mediterranean Sea. Mar. Ecol. Prog. Ser., 164: 107-124.

Gasol, J.M. and C.M. Duarte. - 2000. Comparative analyses in aquatic microbial ecology: how far do they go? FEMS Microbiol. Ecol., 1092: 1-9.

Hanson, R.B., M.T. Álvarez-Ossorio, M.J. Campos, M. Román, G. Santiago, M. Varela and J.A. Yoder. - 1986. Plankton response following a spring upwelling event in the Ria de Arosa, Spain. Mar. Ecol. Prog. Ser., 32: 101-113.

Hoch, M.P. and D.L. Kirchman. - 1993. Seasonal and inter-annual variability in bacterial production and biomass in a temperate estuary. Mar. Ecol. Prog. Ser., 98: 283-295.

Iriberri, J., M. Unanue, B. Ayo, I. Barcina and L. Egea. - 1990. Bacterial production and growth rate estimation from ${ }^{3} \mathrm{H}$-thymidine incorporation for attached and free-living bacteria in coastal waters. Appl. Environ. Microbiol., 56: 483-487.

Kirchman, D.L. - 1992. Incorporation of thymidine and leucine in the subarctic Pacific: aplication to estimating bacterial production. Mar. Ecol. Prog. Ser., 82: 301-309.

Kirchman, D.L. - 1993. Leucine incorporation as a measure of bio- 
mass production by heterotrophic bacteria. In: P.F. Kemp, B.F Sherr, E.B. Sherr and J.J. Cole. (Eds.), Handbook of methods in aquatic microbial ecology, pp. 509-512. Lewis Publishers, Boca Raton.

Kirchman, D.L, and Ducklow, H.W. - 1993. Estimating conversion factors for the Thymidine and Leucine methods for measuring bacterial production. In: P.F. Kemp, B.F. Sherr, E.B. Sherr and J.J. Cole. (Eds.), Handbook of methods in aquatic microbial ecology, pp. 513-517. Lewis Publishers, Boca Raton.

Kirchman, D.L., E. K’Nees and R.E. Hodson. - 1985. Leucine incorporation and its potential as a measure of protein synthesis by bacteria in natural aquatic ecosystems. Appl. Environ. Microbiol., 49: 599-607.

Lee, S. and J.A. Furhman. - 1987. Relationships between biovolume and biomass of Naturally derived Marine Bacterioplankton. Appl. Environ. Microbiol., 53: 1298-1303.

Li, W.K.W., P.M. Dickie, W.G. Harrison and B.D. Irwin. - 1993. Biomass and production of bacteria and phytoplankton during the spring bloom in the western North Atlantic Ocean. Deep Sea Res. II, 40: 307-327.

Lucas, M.I., S.J. Painting and D.G. Muir. - 1986. Estimates of carbon flow through bacterioplankton in the S. Benguela upwelling region based on ${ }^{3} \mathrm{H}$-thymidine incorporation and predator-free incubations. Colloque International de Bactériologie Marine, Actes de Colloque., 3: 375-383.

MacManus, G.B. and W.T. Peterson. - 1988. Bacterioplankton production in the nearshore zone during upwelling off central Chile. Mar. Ecol. Prog. Ser., 43: 11-17.

Morán, X. A. G., J.M. Gasol., L. Arin and M. Estrada. - 1999. A comparison between glass fiber and membrane filters for the estimation of phytoplankton POC and DOC production. Mar. Ecol. Prog. Ser., 187: 31-41.

Norland, S., M. Heldal and O. Tumyr. - 1987. On the relation between dry matter and volume of bacteria. Microb. Ecol., 13: 95-103.

Opshal, S. and R. Benner. - 1997. Distribution and cycling of terrigenous dissolved organic matter in the ocean. Nature, 386: 480-482.

Parsons, T.R., Y. Maita and C.M. Lalli. - 1984. A manual of chemical and biological methods for seawater analysis. Pergamon. Oxford.

Porter, K.G. and Y.S. Feig. - 1980. The use of DAPI for identifying and counting aquatic microflora. Limnol. Oceanogr., 25: 943-948.

Simon, M. and F. Azam. - 1989. Protein content and protein synthesis rates of planktonic marine bacteria. Mar. Ecol. Prog. Ser., 51: 201-213.

Smith D.C. and F. Azam. - 1992. A simple, economical method for measuring bacterial protein synthesis rates in seawater using ${ }^{3}$ H-leucine. Mar. Microb. Food Webs, 6: 107-114.

Sorokin Y.I. - 1981. Microheterotrophic organisms in marine ecosystems. In: A.R. Longhurst (ed.), Analysis of marine ecosystems, pp. 293-342. Academic Press, London.

Sorokin Y.I. and J.E. Kogelschatz. - 1979. Analysis of heterotrophic microplankton in an upweling area. Hydrobiol., 66: 195-209.

Straskraba, M. and A.H. Gnauck. - 1985. Freshwater Ecosystems: Modelling and simulation. Elsevier. Amsterdam.
Tenore, K.R., M. Alonso-Noval, M. Álvarez-Ossorio, L. P. Atkinson, J. M. Cabanas, R. M. Cal, H. J. Campos, F. Castillejo, E. J. Chesney, N. González, R. B. Hanson, C. R. McClain, A. Miranda, M. R. Roman, J. Sánchez, G. Santiago, L. Valdés, M.Varela and J. Yoder. - 1995. Fisheries and oceanography off Galicia, NW Spain: Mesoscale spatial and temporal changes in physical processes and resultant patterns of biological productivity. J. Geophys. Res., 100: 10943-10966.

Unanue, M., B. Ayo, I. Azúa, I. Barcina and J. Iriberri. - 1992. Temporal variability of attached and free-living bacteria in the coastal waters. Microb. Ecol., 23: 27-39.

UNESCO. - 1994. Protocols for the Joint Global Ocean Flux Study (JGOFS) Core Measurements. SCOR-IOC-UNESCO Manuals and Guides. 29.

Valdés, L., M.T. Álvarez-Ossorio, A. Lavín, M. Varela and R. Carballo. - 1991. Ciclo anual de parámetros hidrográficos, nutrientes y plancton en la plataforma continental de La Coruña (NO, España). Bol. Inst. Esp. Oceanogr., 7: 91-138.

Valiela, I. - 1995. Marine ecological processes. 2nd ed. Springer, New York.

Van Looij, A. and B. Riemann. - 1993. Measurements of bacterial production in coastal marine enviroments using leucine: application of a kinetic approach to correct for isotope dilution. Mar. Ecol. Prog. Ser., 102: 97-104

Varela, M. - 1992. Upwelling and phytoplankton ecology in Galician (NW Spain) rias and shelf waters. Bol. Inst. Esp. Oceanogr., 8: 57-74

Varela, M., M.T. Álvarez-Ossorio, L. Valdés, R. Cal, A. Miranda, G. Santiago and E. Costas. - 1988. Partición de la materia orgánica particulada en el área de afloramiento de la plataforma de Galicia (NO España) durante la campaña Breogán 684. Bol. Inst. Esp. Oceanogr., 5: 97-108.

Varela, M., A. Bode., M.T. Álvarez, R. Prego, M. Canle, B. Casas, J. Lorenzo, D. Mariño, I. González, R. Carballo and M. Vilas. - 1996. Sistema pelágico. In: Seguimiento de la contaminación producida por el accidente del buque "Aegean Sea”, pp. 15-63. Ministerio de Medio Ambiente, Madrid.

Varela, M.M., A. Bode, N. González, C. Rodríguez and M. Varela. - (in press). Fate of organic matter in the Ria de Ferrol (Galicia, NW Spain): uptake by pelagic bacteria versus particle sedimentation. Acta Oecologica.

Wiebinga, C.J., J.W. Veldhuis and J.W. De Baar. - 1997. Abundance and productivity of bacterioplankton in relation to seasonal upwelling in the northwest Indian Ocean. Deep-Sea Res., 44: 451-476.

White, P.A. J. Kalff, J.B. Rasmussen and J.M. Gasol - 1991. The effect of temperature and algal biomass on bacterial production and specific growth rate in freshwater and marine habitats. Microb. Ecol. 21: 99-118.

Yentsch, C.S. and D.W. Menzel. - 1963. A method for the determination of phytoplankton chlorophyll and phaeophytin by fluorescence. Deep-Sea Res., 10: 221-231.

Zdanowski, M.K. and F.G Figueiras. - 1997. Relationships between the abundance of bacteria and other biota and the hydrographic variability in the Ría de Vigo, Spain. Mar. Ecol. Prog. Ser. 147: $257-267$

Scient. ed.: D. Vaqué 
